\title{
UPAYA PELAKSANAAN DAN PEMANTAUAN KEJADIAN KIPI PADA PELAKSANAAN VAKSINASI COVID-19
}

\author{
Rebekah Malik $^{1}$, Dewi Indah ${ }^{2}$, Djung Lilya Wati ${ }^{3}$,Sari Mariyati Dewi ${ }^{4}$ dan Linda $^{\text {, }}$ \\ Budiarso 5
}

\author{
${ }^{1}$ Bagian Patologi Klinik Fakultas Kedokteran Universitas Tarumanagara, \\ Email: rebekahm@fk.untar.ac.id \\ ${ }^{2}$ Bagian Ilmu Kesehatan Masyarakat Fakultas Kedokteran Universitas Tarumanagara, \\ ${ }^{3}$ Bagian Ilmu Penyakit Saraf, Fakultas Kedokteran Universitas Tarumanagara, \\ ${ }^{4}$ Bagian Histologi, Fakultas Kedokteran Universitas Tarumanagara, \\ Email: sarid@fk.untar.ac.id \\ ${ }^{5}$ Bagian Mikrobiologi, Fakultas Kedokteran Universitas Tarumanagara, \\ Email: linda.b.arief@gmail.com
}

\begin{abstract}
Post-Immunization Adverse Events (AEFI) are medical events that occur after immunization, and need attention. given counseling and IEC media about COVID-19 prevention and COVID-19 vaccination. The purpose of this PKM activity is to provide health promotion services through monitoring and education related to the anticipation of the Covid 19 vaccine AEFI. The benefits of the PKM activity are that vaccination participants are protected from AEFIs and the PKM TEAM contributes to caring for others in the health sector, especially the implementation of promotive and preventive efforts. The short-term target of the PKM activity is the Covid-19 vaccination participants, namely the elderly to avoid AEFIs and the long-term target is to improve the health status of the Covid-19 vaccination participants and assist the "Jakarta Responding Corona" program. March 27, 2021. The number of participants who can be vaccinated is 156 people consisting of 153 elderly and 2 health workers and 1 ASN. Of the 156 participants who were vaccinated, none experienced a post-immunization follow-up event (AEFI).
\end{abstract}

Keywords: AEFI, covid19 vaccination, promotive and preventive

\begin{abstract}
ABSTRAK
Kejadian Ikutan Pasca Imunisasi (KIPI) merupakan kejadian medik yang terjadi setelah dilakukan imunisasi, dan perlu mendapat perhatian sesuai dengan alur pelayanan vaksinasi COVID-19 yaitu pada meja pelayanan vaksin nomor 4. Tenaga medis mempersilakan penerima vaksinasi untuk menunggu selama 30 menit di ruang observasi dan diberikan penyuluhan tentang KIE, pencegahan COVID-19 dan vaksinasi COVID-19. Tujuan Kegiatan PKM ini adalah memberikan pelayanan promosi kesehatan melalui pemantauan dan edukasi terkait antisipasi KIPI yang dapat timbul paska vaksin Covid 19. Manfaat dari kegiatan PKM adalah peserta vaksinasi terhindar dari KIPI serta TIM PKM berkontribusi dalam kegiatan kepedulian bagi sesama di bidang kesehatan terutama penerapan pelaksanaan upaya promotif dan preventif. Target jangka pendek kegiatan PKM adalah peserta vaksinasi Covid-19 yaitu lansia terhindar KIPI dan target jangka panjang adalah meningkatkan derajat kesehatan peserta vaksinasi Covid-19 dan membantu program "Jakarta Tanggap Corona".Pelaksanaan vaksinasi dalam upaya pencegahan Covid-19 dilakukan pada tanggal 24 - 27 Maret 2021. Jumlah peserta yang dapat divaksinasi sebanyak156 orang terdiri dari 153 lansia dan 2 tenaga kesehatan dan 1 ASN. Dari 156 peserta yang divaksin, tidak ada yang mengalami kejadian ikutan paska imunisasi (KIPI).
\end{abstract}

Kata Kunci : KIPI, vaksinasi covid19, promotif dan preventif

\section{PENDAHULUAN}

Pada tanggal 31 Desember 2019 kondisi dunia berubah karena sekelompok kasus pneumonia yang tidak diketahui penyebabnya (Zhu N,2020). Agen penyebabnya diidentifikasi sebagai Corona virus dinamai SARS-CoV-2, dan spektrum klinis sebagai virus korona yang disebut Corona Virus Disease yang ditemukan tahun 2019 (COVID-19). (WHO,2020). Virus itu menyebar melalui droplet yang dikeluarkan oleh penderita melalui saluran pernapasan sangat menular antar manusia wabah dengan cepat meningkat ke seluruh dunia dan menjadi pandemi pada 11 Maret 2020. (WHO,2020). Sejak 20 Desember 2020, jumlah kasus COVID-19 telah mencapai lebih dari 75 juta orang dengan lebih dari 1,6 juta kematian secara global. Di Asia 
Tenggara - dengan total 19.390 kematian atau case fatality rate (CFR) 3,0\% sedang di Indonesia, total kasus mencapai 650 ribu dengan kasus aktif hampir 100 ribu, (Roser M,2020).

Vaksinasi adalah upaya suatu proses dalam tubuh, dimana seseorang menjadi kebal atau terlindungi dari suatu penyakit sehingga apabila suatu saat terpajan dengan penyakit tersebut maka tidak akan sakit atau hanya mengalami sakit ringan. Vaksin adalah produk biologi yang berisi antigen berupa mikroorganisme atau bagiannya atau zat yang dihasilkannya yang telah diolah sedemikian rupa sehingga aman, yang apabila diberikan kepada seseorang akan menimbulkan kekebalan spesifik secara aktif terhadap penyakit tertentu. Vaksin mendorong pembentukan kekebalan spesifik tubuh agar terhindar dari tertular ataupun kemungkinan sakit berat. Selama belum ada obat yang defenitif untuk COVID-19, maka vaksin COVID-19 yang aman dan efektif serta perilaku taat terhadap protokol kesehatan adalah upaya perlindungan yang bisa kita lakukan agar terhindar dari penyakit COVID-19. (Kemenkes,2021)

Vaksin mempersiapkan sistem kekebalan untuk melawan virus. Vaksin diharapkan dapat menyelamatkan jutaan nyawa dan untuk selanjutnya memberikan imunitas terhadap komunitas sehingga tercipta komunitas yang sehat. (WHO,2021). Saat orang divaksinasi terhadap penyakit Coronavirus-19 (COVID-19), virus tidak dapat ditularkan dengan mudah dari manusia kepada orang, dan komunitas cenderung tidak terikat COVID-19 yang disebut "kekebalan komunitas atau "Kekebalan kawanan". (Aschwanden C,2021). Banyaknya orang yang divaksin akan berdampak dengan semakin kecil kemungkinan penyebaran COVID-19. Tingkat vaksinasi yang tinggi melindungi kita sekaligus populasi rentan seperti bayi, orang tua, wanita hamil, pekerja kesehatan lini pertama dan orang-orang dari segala usia dengan sistem kekebalan yang terganggu, yang tidak sepenuhnya belum divaksinasi.( Polack FP,2020).

Kejadian Ikutan Pasca Imunisasi (KIPI) yang terjadi mempunyai gejala dari ringan sampai berat, tergantung dari masing-masing orang. Reaksi yang mungkin terjadi setelah vaksinasi COVID-19 hampir sama dengan vaksin yang lain. Beberapa gejala tersebut antara lain reaksi lokal, seperti nyeri, kemerahan, bengkak pada tempat suntikan dan reaksi lokal lain yang berat, misalnya selulitis. Reaksi sistemik seperti demam, nyeri otot seluruh tubuh (myalgia), nyeri sendi (atralgia), badan lemah, dan sakit kepala. Reaksi lain, seperti alergi misalnya urtikaria, oedem, reaksi anafilaksis, dan syncope (pingsan).

Berdasarkan hal tersebut perlu upaya antisipasi yang dipersiapkan untuk menghadapi peluang efek

samping dari pemberian vaksin. Untuk pemantauan dan penanggulangan KIPI, maka Menteri Kesehatan membentuk Komite Nasional Pengkajian dan Penanggulangan KIPI, serta Gubernur membentuk Komite Daerah Pengkajian dan Penanggulangan KIPI. Berdasarkan laporan yang masuk, sebagian besar kasus KIPI yang terjadi adalah KIPI ringan atau koinsiden (tidak berhubungan dengan pemberian imunisasi. Apabila terjadi KIPI, baik KIPI ringan maupun KIPI serius, perlu dilakukan edukasi ke masyarakat dan melaporkan kepada petugas kesehatan yang ada di fasilitas pelayanan kesehatan yang memberikan layanan vaksinasi atau ke puskesmas terdekat. upaya antisipasi yang dipersiapkan untuk menghadapi peluang efek samping dari masing-masing jenis vaksin. (Kemenkes, 2021)

\section{Permasalahan mitra}

Kejadian Ikutan Pasca Vaksinasi atau biasa disebut KIPI merupakan kejadian medik yang diduga berhubungan dengan vaksinasi. Pemerintah menetapkan pelaksanaan vaksinasi COVID-19 sudah masuk pada Tahap 2 dan target kelompok LanjutUsia (usia 60 tahun keatas) dan pekerja publik. Vaksinasi target kelompok ini dimulai di Jakarta dan ibu kota provinsi untuk seluruh provinsi di Indonesia. Namun dalam fase awal diprioritaskan dahulu untuk Jawa dan Bali dimana lebih dari 65 persen kasus Covid-19 nasional tercatat. 
FK UNTAR bermaksud untuk membantu program pelaksanaan vaksinasi Covid -19 dengan menyelenggarakan kegiatan vaksinasi di Universitas Tarumanagara dengan sasaran Warga Lansia Jakarta Barat sekitar Universitas Tarumanagara. Kegiatan dilaksanakan selama 4 hari mulai dari jam 8.00-15.00. Untuk mengantisipasi KIPI yang terjadi pasca vaksinasi Covid-19 maka tim kedokteran Universitas Tarumanaga bermaksud melakukan kegiatan PKM upaya pelaksanaan dan pemantauan kejadian KIPI pada pelaksanaan vaksinasi covid-19 di Universitas Tarumanagara.

\section{METODE PELAKSANAAN PKM}

Program vaksinasi Covid-19 sudah dilaksanakan dengan prioritas lansia. KIPI dapat terjadi setelah vaksinasi. Dalam upaya mengantisipasi terjadinya Kejadian Ikutan Pasca Imunisasi dalam pelaksanaan vaksinasi maka masyarakat diminta menunggu 30 menit setelah disuntik vaksin. Penerima vaksin harus menunggu selama 30 menit setelah divaksinasi. Waktu menunggu 30 menit dilakukan untuk mengobservasi Kejadian Ikutan Pasca Imunisasi (KIPI).

Langkah yang dilakukan sesuai dengan Alur Pelayanan Vaksinasi COVID-19 yaitu pada meja pelayanan vaksin nomor 4, penerima vaksinasi menunggu selama 30 menit di ruang observasi dan diberikan penyuluhan dan media KIE tentang pencegahan COVID-19 melalui 3M dan vaksinasi COVID-19. Tim medis juga menerangkan terkait reaksi KIPI yang mungkin terjadi yaitu untuk reaksi ringan lokal seperti nyeri, bengkak dan kemerahan pada tempat suntikan, petugas kesehatan dapat menganjurkan penerima vaksin untuk melakukan kompres dingin pada lokasi tersebut dan meminum obat paracetamol sesuai dosis. Untuk reaksi ringan sistemik seperti demam dan malaise, petugas kesehatan dapat menganjurkan penerima vaksin untuk minum lebih banyak, menggunakan pakaian yang nyaman, kompres atau mandi air hangat, dan meminum obat paracetamol sesuai dosis.

\section{HASIL DAN PEMBAHASAN}

Pelaksanaan vaksinasi dalam upaya pencegahan Covid-19 dilakukan pada tanggal 24 - 27 Maret 2021. Jumlah peserta yang dapat divaksinasi sebanyak156 orang terdiri dari 153 lansia dan 2 tenaga kesehatan dan 1 ASN. Dari 156 peserta yang divaksin, tidak ada yang mengalami Kejadian ikutan paska imunisasi (KIPI). Tujuan Kegiatan PKM ini adalah memberikan pelayanan promosi kesehatan melalui pemantauan dan edukasi terkait antisipasi KIPI vaksin Covid 19. Manfaat dari kegiatan PKM adalah peserta vaksinasi terhindar dari KIPI serta TIM PKM berkontribusi dalam kegiatan kepedulian bagi sesama di bidang kesehatan terutama penerapan pelaksanaan upaya promotif dan preventif. Target jangka pendek kegaiatn PKM adalah peserta vaksinasi Covid-19 yaitu lansia terhindar adri KIPI dan target jangka panjang adalah meningkatkan derajat kesehatan peserta vaksinasi Covid-19 dan membantu program "Jakarta Tanggap Corona".

Tabel 1 . Peserta Vaksinasi Covid 19

\begin{tabular}{lccccc}
\hline Peserta Vaksinasi & 24 Maret & 25 Maret & 26 Maret & 27 Maret & Jumlah \\
\hline Terdaftar & 65 & 42 & 20 & 58 & \\
\hline Datang & 49 & 42 & 20 & 49 & \\
\hline Vaksin & $\mathbf{4 6}$ & $\mathbf{4 1}$ & $\mathbf{2 0}$ & $\mathbf{4 9}$ & $\mathbf{1 5 6}$ \\
\hline Tunda Vaksin & 3 & 1 & 0 & 0 & \\
\hline Lansia Vaksin & 44 & 41 & 19 & 49 & \\
\hline Nakes Vaksin & 2 & 0 & 0 & 0 & \\
\hline Lain2 Vaksin & 0 & 0 & 1 & 0 & \\
\hline
\end{tabular}


Menurut WHO, KIPI adalah setiap kejadian medis yang tidak diinginkan, yang terjadi setelah pemberian imunisasi. KIPI dapat terjadi dengan menimbulkan gejala sedang hingga berat. Gejala berat termasuk sangat jarang terjadi. Gejala berat yang diantisipasi adalah reaksi syok anafilaktik. Reaksi syok anafilaktik adalah reaksi alergi berat yang menyebabkan penurunanan tekanan darah secara drastis sehingga menyebabkan sulit bernapas bahkan kehilangan kesadaran. Reaksi ini biasanya terjadi dalam waktu singkat hingga 30 menit setelah disuntik vaksin. Setelah lewat dari 30 menit, reaksi ini biasanya tidak terjadi lagi dan penerima vaksin dapat beraktivitas seperti biasa. Hal inilah yang menyebabkan penerima vaksin harus menunggu 30 menit terlebih dahulu sebelum pulang. Masyarakat penerima vaksin tidak perlu khawatir karena dokter dan ahli medis / petugas vaksin yang menyuntikkan vaksin sudah dilengkapi dengan anafilaktik kit untuk menangani reaksi alergi tersebut. Setiap fasilitas kesehatan penyelenggara vaksinasi wajib melakukan pencatatan dan pelaporan KIPI yang terjadi. Adanya program vaksinasi yang telah berjalan saat ini, tidak lantas membuat kita lengah menjalankan protokol kesehatan.

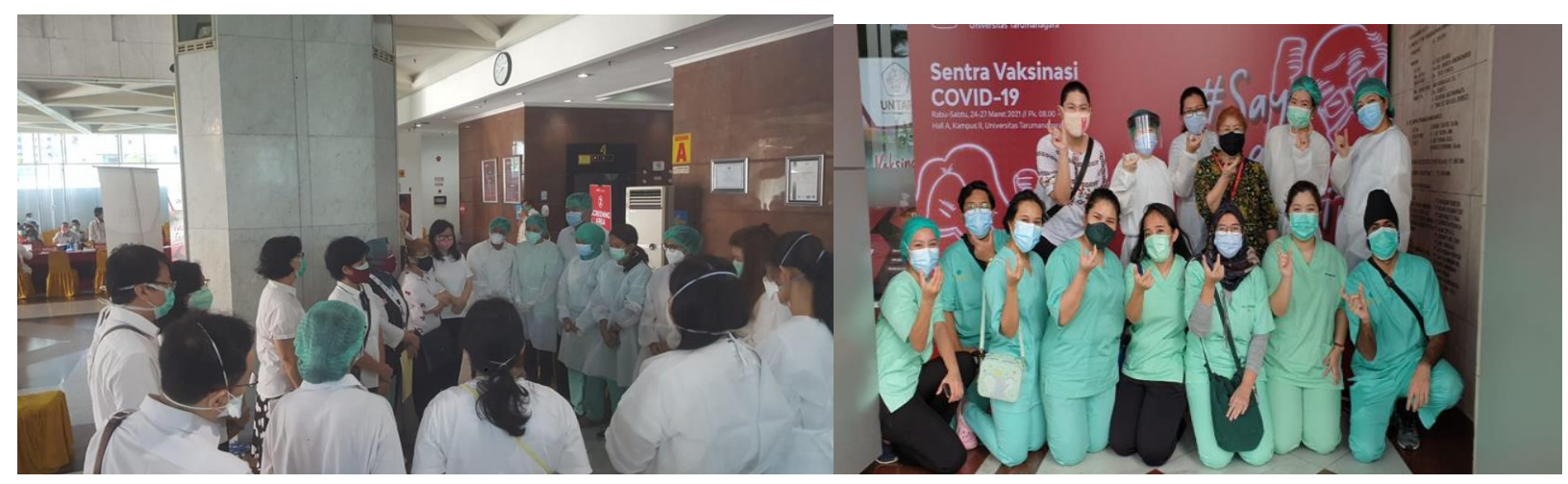

Gambar 1

Kegiatan vaksinasi Covid-19

\section{KESIMPULAN}

Universitas Tarumanagara khususnya fakultas kedokteran melakukan berbagai macam kegiatan untuk membantu preventif terhadap COVID-19 dan membantu program "Jakarta Tanggap Corona". UNTAR menjadi Sentra Vaksinasi dan monitoring KIPI paska dilakukan vaksinasi. Dari pelaksanaaan vaksinasi tanggal 24-27 Maret 2021 terhadaap 156 peserta, tidak ditemukan adanya KIPI. Kegiatan ini diharapkan dapat berjalan berkesinambungan serta mensosialisasi pencegahan COVID-19 di lingkungan Universitas Tarumanagara.

\section{Ucapan Terima Kasih (Acknowledgement)}

TIM PKM mengucapkan terima kasih kepada Yayasan UNTAR, Rektor UNTAR beserta jajarannya, Dekan FK UNTAR beserta jajarannya, Lembaga Penelitian dan Pengabdian kepada Masyarakat UNTAR atas sarana, pendanaan serta dukungan dalam kegiatan ini. Terima kasih juga disampaikan kepada seluruh peserta, tim dokter FK UNTAR yang telah mengikuti kegiatan bakti kesehatan ini, sehingga kegiatan dapat terlaksana dengan baik dan lancar. Terima kasih juga kepada Panitia SENAPENMAS yang sudah memberikan kesempatan untuk berpatisipasi pada kegiatan SENAPENMAS 2021

\section{REFERENSI}

Aschwanden C. (2020). The false Promise of HERD Immunity. Nature. 2020;587(7832):26-8. 


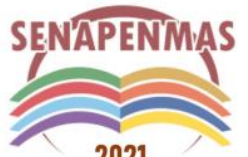

2021
Seminar Nasional Hasil Penelitian dan Pengabdian Kepada Masyarakat 2021 Pengembangan Ekonomi Bangsa Melalui Inovasi Digital Hasil Penelitian dan Pengabdian Kepada Masyarakat Jakarta, 21 Oktober 2021

Kemenkes. (2021). Final SK Dirjen Juknis Vaksinasi COVID-19 02022021.pdf. https://covid19.go.id/storage/app/media/Regulasi/2021/Januari/Final\%20SK\%20Dirjen\%2 0Juknis\%20Vaksinasi\%20COVID-19\%2002022021.pdf

Kemenkes. (2021). Menunggu 30 menit setelah vaksinasi covid19. https://promkes.kemkes.go.id/flyer-menunggu-30-menit-setelah-divaksinasi-covid-19

Kemenkes. (2021). Seputar Vaksinasi Secara Umum. https://kesmas.kemkes.go.id/assets/uploads/contents/others/FAQ_VAKSINASI_COVID_ call_center.pdf

Koesnoe, S. (2021). Teknis Pelaksanaan Vaksin Coviddan Antisipasi KIPI. Satgas Imunisasi Dewasa PB PAPD

Polack FP, Thomas SJ, Kitchin N, Absalon J, Gurtman A, Lockhart S, et al.(2020). Safety and Efficacy of the BNT162b2 mRNA Covid-19 Vaccine. N Engl J Med. 2020;383(27):260315.

Roser M, Ritchie H, Ortiz-Ospina E, Hasell J.(2020).Coronavirus pandemic (COVID-19). Our World in Data Internet]. Available from: https://ourworldindata.org/coronavirus

Satari,HI. (2021). Penanganan, Rujukan Dan Pembiayaan KIPI Vaksinasi Covid-19.

WHO. (2021). COVID-19 vaccines [Internet]. WHO Library Cataloguing-in-Publication Data. 2021 [cited 2021 Jan 21]. Available from: https:/www.who.int/emergencies/ diseases/novel-coronavirus-2019/covid-19-vaccines 2.

WHO. (2020). Statement regarding cluster of pneumonia cases in Wuhan, China [Internet]. [cited 2020 Dec 17]. Available from: https://www.who.int/china/news/ detail/09-01-2020who-statement-regarding-clusterof-pneumonia-cases-in-wuhan-china

WHO. (2020) Director-General's opening remarks at the media briefing on COVID-19 - 11 March 2020. [cited 2020 Dec 17]. Available from: https://www. who.int/directorgeneral/speeches/detail/who-directorgeneral-s-opening-remarks-at-the-media-briefing-oncovid-19---11-march-2020

Zhu N, Zhang D, Wang W, et al. (2020) A novel coronavirus from patients with pneumonia in China, 2019. N Engl J Med. 2020 Feb 20;382(8):727-33. 
Seminar Nasional Hasil Penelitian dan Pengabdian Kepada Masyarakat 2021

Pengembangan Ekonomi Bangsa Melalui Inovasi Digital Hasil Penelitian dan

Pengabdian Kepada Masyarakat

Jakarta, 21 Oktober 2021

(halaman kosong) 